\title{
EFL Instructors' Beliefs and Practices of Formative Assessment in Teaching Writing
}

\author{
Zelalem Berhanu Guadu \\ Department of English Language and Literature, College of Social Sciences and Humanities, Debre Markos University, \\ Debre Markos, Ethiopia \\ Emily Joy Boersma \\ Department of English Language and Literature, Faculty of Humanities, Bahir Dar University, Bahir Dar, Ethiopia
}

\begin{abstract}
The purpose of this study was twofold: firstly to assess EFL instructors' beliefs and practices of formative assessment in teaching writing, and secondly to determine the relationship between their beliefs and practices of formative assessment. Utilizing a mixed methods approach and an explanatory design, both qualitative and quantitative data were gathered and analyzed. The data were generated from 25 EFL instructors teaching writing skills via a five point Likert scale questionnaire and semi-structured interview as well as students' assessment papers. The Data from the close-ended questionnaire were analyzed through descriptive and inferential statistics whereas those from open-ended questionnaire, interview and students' papers were analyzed through description and thematic categorization. The findings showed that writing skills teachers have a positive belief toward the importance of formative assessment, and they practice it at medium level. Moreover, the statistical analysis showed a positive, moderate and significant correlation between instructors' beliefs and their practices $(r(23)=.569, p<0.01)$. Nevertheless, the triangulation made with the qualitative data revealed instructors' beliefs and their actual practices are incongruent.
\end{abstract}

Index Terms - formative assessment, belief, practice, EFL instructors

\section{INTRODUCTION}

This contemporary world needs people to develop a high level of competence and knowledge to adjust themselves with the rapidly changing environment and the increasing demands of modern technological society. In this respect, English language plays two key roles. First, it is a global language which serves as a medium of communication among people of the world. Second, it is serves as a learning tool at different levels of education. Literacy in writing in English is especially essential in the academic world as most of the activities require a good writing ability.

Although literacy in English is very essential at any level of education, its value at higher education level is more crucial because in a university, writing is not just a standardized system of communication; it is an essential tool for learning as well (Weigle, 2002). This is why the value of written communication in English is becoming increasingly essential (Cumming, 2009). Learning to write in English has become more important and consequential for academic study, work and communications than it was 30 years ago (ibid).

In the current Ethiopian education system, it is mandatory to learn English as a subject from grade one up to secondary school level and to use it as a medium of instruction from grades seven (for some subjects) and nine (for all subjects except Amharic-the national language of the country) up to university level. In addition to their long years of exposure to English language both as a medium of instruction and as a subject, all first year university students take two English language courses (Communicative English Skills and Basic Writing skills) with the intention of equipping them with the basic skills to ease the language challenge they face when they learn different subjects. Among the skills, writing has received more emphasis than others, may be, due to its pivotal role for students' success in learning. The more emphasis offered to the skill is evident from the fact that it is treated as the other skills in the "Communicative English Skills' course, and writing alone is taught in 'Basic Writing Skills Course', which illustrates that more time and emphases has been given to the development of writing skill.

However, with all this exposure and instruction, Ethiopian university students often receive complaints from instructors and other bodies about their low level of English language skills among which writing is the more serious one. Instructors claim that the students' ability to use English for their studies, especially to write grammatically accurate and meaningful sentences is deteriorating (Haregewain, 2008; Bekele, 2011; Zewdu, 2012). In addition, Geremew (1999) and Alamirew (2005) state that graduates are unable to express themselves clearly and currently in writing in English. The present researcher also shares this concern from his experience of teaching writing courses at Debre Markos University.

To remedy such writing problem, instructors' beliefs and practice of assessment are potential areas for investigation because it is assumed that the students' academic failure in general and writing ability in particularly is associated with teachers' assessment beliefs and their actual practice in the classroom. Abiy (2013), in this regard, underscores that 
assessment practices shape the instructional processes, and as a result of this learning can be changed. This translates that assessment is the driving force of the teaching and learning process i.e. if there is good assessment practice, sound instruction will follow and this will results in effective learning.

In the teaching of writing, the implementation of formative assessment is fundamental as it links instruction to learning and to writing improvement (Cumming, 2009). In addition, since writing is a procedural activity, as advocated by proponents of the process approach, it needs continuous formative assessment (feedback) from different bodies, such as self, peer, and teacher at the different stages of the writing process so as to provide writers with opportunity to revise their writing. In recent years, the traditional assessment of writing which focuses on the written products or on how well or badly students performed the writing is giving way to the process-oriented one which utilizes the formative potential of assessment for promoting learning through the active involvement of learners and teachers at the different stages in the writing process (Lee, 2011). This implies that writing teachers need to use formative assessment with the process-oriented approach of teaching. This approach is believed to not only make students perform better in writing and be responsible for their own learning but also to contribute much in developing their self-confidence in writing (Sadler, 1989; Macfarlane-Dick and Nicol, 2006).

Understanding the close link between assessment and instruction, few attempts have been made locally to address assessment related issues. Mebea (2008) studied the challenges of implementing continuous oral assessment in EFL classes focusing Debre-Birhan teachers' college. The study revealed both the teacher-educators and student-teachers have positive attitude towards continuous oral assessment though it is a neglected area of practice. The study pointed out that students' linguistic background, structural constraints, absence of college level assessment policy, inadequate use of informal continuous oral assessment methods, negligence of formative continuous assessment were the major factors affecting the practice. Similarly, Dagne (2009) explored EFL instructors' practice of continuous assessment at Jimma Teachers College and indicated $70 \%$ of the teachers did not use continuous assessment due to inadequate training, workload, extra responsibilities and large class size. In addition, Habtamu's (2012) investigation of EFL instructors' implementation of continuous assessment in Dilla University showed that instructors in the university had inadequate knowledge about the principles and purposes of continuous assessment. The findings additionally showed that instructors used assessment devices mainly to judge students' language performance, not to gear the teaching and learning. Abiy (2013), on his part, studied high school teachers' and students' perceptions, attitudes, and actual practices of continuous assessment and concluded that continuous assessment was not properly implemented and its function to diagnose student's problems and modify the teaching was found to be very limited and even absent in most cases.

One can learn that the above few studies attempted to investigate assessment-related problems at secondary school and college settings; however, none of them touched up on EFL teachers' beliefs and practices of formative assessment in teaching writing in a university context. Therefore, the present study could fill this gap by investigate EFL teachers' beliefs toward formative assessment and their actual practice in the writing class with particular reference to Debere Markos University. The study aimed to answer the following three major questions:

1. What belief do EFL instructors hold on the importance of formative assessment?

2. To what extent do EFL instructors practice formative assessment in their writing class?

3. What is the relationship between EFL instructors' beliefs towards and their actual practices of formative assessment?

\section{LITERATURE REVIEW}

\section{A. What Formative Assessment Is}

The term formative assessment has been defined by different scholars. For Black and William (2003:2), formative assessment is "any assessment for which the first priority is to serve the purpose of advancing student learning." These scholars maintain that formative assessment does not aim to make schools accountable, or to provide students with certificates. Instead it targets generating feedback about teaching and students' learning for making improvements on the process. Sadler (1998), on his part, defined it as a kind of assessment that is intended to produce feedback on performance to enhance and accelerate learning. Black and Wiliam (2009) also defined it as an activity which refers to all activities undertaken by teachers, and/ or by students, which provide information to be used as feedback to modify the teaching and learning activities in which they are engaged. Therefore, formative assessment is an activity whose major intent is not to measure students' proficiency(what they did wrong or right), nor to certify their achievement level or be accountable, but rather to advance student learning and instruction through identification of weaknesses and taking remedial actions to repair them.

\section{B. Difference between Formative Assessment and Summative Assessment}

In 2011, the Cross Sectoral Assessment Working Party stated that formative assessment is assessment for learning which is often used at the onset of an instructional period and during the process of instruction when teachers aim to check for student understanding. Through diagnostic tools, this kind of assessment determines what students already know and where there are gaps. Formative assessment also includes assessment as learning, where students reflect on and monitor their own progress. The information gained via this assessment guides teachers' decisions in how to 
enhance teaching and learning. In addition, it enables students to learn through the process of feedback and provides opportunities to practice and improve. As students reflect on and monitor their progress this process effectively becomes assessment as learning and contributes to students planning future learning goals. As Campbell and Norton (2007) claim, the feedback which emanates from formative assessment raises performance in all sorts of learning.

However, summative assessment is different in that it is assessment of learning which is usually used towards and at the end of the instruction period. Teachers document the culmination of students' learning achievements through tasks that invite students to demonstrate their mastery and knowledge of the course content. The data from summative assessment provides teachers with information about how effective teaching strategies have been, time needed for instruction and how to improve teaching for future students, not for students of the present.

In summary, formative assessment differs from the summative one in that formative assessment targets how to improve learning and have prospective functions whereas summative assessment aims at making judgment about the teaching and learning and it is concerned with summarizing the achievement status of a student. Summative assessment is geared towards reporting at the end of a chapter or a course. In fact, if properly used, summative assessment can serve formative purposes provided that teachers take remedial actions based on the evidence from the summative assessment.

\section{Teachers'Beliefs and Their Assessment Practices}

EFL teachers' beliefs refer to teachers' behaviors with some individual teaching practices which reflect their beliefs about teaching and learning a foreign language (Bauch, 1984; Graves, 2000; Huang, 1997) quoted in Lumpur (2013). Substantial evidence from studies in the past two decades has shown that language teachers' beliefs are complex, dynamic, context-sensitive and systematic depending on the nature of the subject, their teaching experience, the context they teach in, etc. (Zheng, 2015). Teachers' beliefs are consistently shown to have a powerful influence on their practice, but a good number of studies have also shown that there are large discrepancies between teachers' reported beliefs and their observed classroom practice (Ibid), and the researches pointed out that this may happen so due to contextual factors, such as social, institutional, instructional and physical settings in which teachers work.

Teachers' beliefs have a key role in implementing assessment policy reforms as much of the policies are implemented by teachers. Their beliefs are mostly shaped by a person's interactions with peers in daily life as well as his/her personal experiences and interpretations. Teachers should utilize assessment information to modify their teaching based on students' needs and provide students with formative feedback that moves learning forward (Leahy, Lyon, Thompson \& William, 2005) quoted in Lumpur (2013). Teachers need to understand the rational for using assessment to improve learning. Thus, it is crucial to find out teachers' appreciation of assessment as well as their assessment roles.

\section{Assessment and Writing}

In second/foreign language writing, assessment has traditionally focused on the written products and how well (or badly) students perform in writing (Lee, 2011). Such assessment is more retrospective than prospective, that is, it gives information about what students did in the past and it does not point out anything regarding what learners should do in the future. Therefore, it holds little value for teaching and learning. Weigle (2002) quoting Bachman and Palmer (1996) implicates that language assessment, of which writing assessment is a subset, is carried out for two main purposes. The primary purpose is to make inferences about the students' language ability (performance), and the other is to make decisions based on the inferences. The decisions may be either to report the students' level of learning (summative purpose) or to plan remedial actions in order to fill the learners' learning gaps.

In recent years, with a major paradigm shift in assessment and evaluation in English language teaching, writing assessment informed primarily by a product and summative orientation, is considered increasingly inadequate because this kind of assessment fails to capture the formative potential of assessment for promoting learning. A formative approach to assessment, on the other hand, focuses more on inquiry (i.e. discovering, diagnosing and understanding) and the opportunities assessment provides for improving teaching and learning. To exploit the potential of formative assessment in the writing classroom, it is obvious that classroom assessment practices be geared towards enhancing student learning (Lee, 2011)).

\section{E. The Role of Feedback for Formative Assessment of Writing}

Feedback, in the writing classroom, refers to "the information that comes back from readers to the writer" (Elashri and Elshirbin, 2013:4). This information can generally emanate from two main sources: Internal and external. The internal feedback comes from the writer (the student) assessing his/her work based on the previously set goal and success criteria. On the other hand, external feedback comes from peers, the teacher, etc reading and assessing that work. Whatever the source, the information by itself is not feedback; it becomes feedback only when it is used to close the gap between the current (actual) level and the reference level of learning. In other words, the feedback must be used for future adjustment of teaching or/and learning. Feedback has a pivotal position in the process of formative assessment (Sadler, 1989; Brookhart, 2008; Heritage, 2010) because what makes an assessment formative is the presence of feedback and how it functions for future learning and teaching.

Studies on the nature of feedback that is most beneficial to learning reveal that the structure, focus and amount of feedback are important points to consider (Black and Wiliam, 1998). During the teaching-learning cycle, some types of 
feedback, for example, those that are evaluative and compare one's performance with others' can have a negative effect on learning and motivation by convincing students that they lack ability and reducing their desire to exert effort to learn (Ibid). Feedback should constitute three basic elements about a task: what was done well, what needs improvement, and how to improve it. This information can be communicated orally, in writing, or as a question that causes students to reflect. Effective feedback provision should focus on the learning goals and success criteria identified for accomplishing the task (Heritage, 2008).

\section{METHOD}

This study used a mixed methods approach in which both qualitative and quantitative methods of data gathering and analysis were applied. The study employed explanatory design which started with collection and analysis of quantitative data from close-ended questionnaire items and followed by the subsequent collection and analysis of qualitative data from open-ended questionnaire items, semi-structured interview and students' sample marked paragraph and essay papers.

\section{A. Participants of the Study}

The total population for this study were 27 Debre Makos University EFL instructors (25 males and 2 females) teaching writing skills course. The samples' teaching experience (in university and elsewhere) ranged from five to twenty years and all of them are qualified with M.A/M.Ed. in teaching English as a foreign language (TEFL). All of them were selected for the study using comprehensive sampling technique. Out of the 27 instructors, two of them (a male and a female) did not return the questionnaire and they were excluded from the study. Thus, the total size of the samples came to be 25 (24 males and 1 female).

\section{B. Instruments}

Three data gathering instruments, namely questionnaire, semi-structured interview and document were used for this study. The questionnaire included 33 adapted items (30 close-ended, 3 open-ended). The internal consistency of the items was checked to be Cronbach's alpha $\alpha=.78$. The close-ended items of the questionnaire had three sub-scales. The first category included 10 items seeking instructors' beliefs toward the importance of formative assessment to enhance instruction and student learning. The second category (11items) aimed to know instructors' perceived practice of formative assessment for monitoring student learning. The third one, consisting of 10 items, concerns identifying instructors' perceived practice of formative assessment for scaffolding student learning. In addition to the close-ended items, three open-ended questions were employed to gather more data from the participants. Moreover, semi-structured interview and sample students' marked paragraphs and essays were used as additional data gathering tools. The qualitative data helped to dig out further information about the respondents' beliefs and practices of formative assessment and to triangulate it with the information obtained from the questionnaire.

\section{DATA ANALYSIS}

\section{A. Analysis of the Quantitative Data}

In this section, data from the close-ended items of the questionnaire were analyzed using descriptive and inferential statistics.

To determine the level of instructors' beliefs and their practice of formative assessment, the researcher set measurement criteria. Accordingly, over all mean scores of greater than or equal to 4.0, or greater than or equal to $80 \%$ agreement was very good. Over all mean scores of between 3.0 and 4.0, or between $60 \%$ and $80 \%$ agreement was medium and those of less than 3.0 , or $60 \%$ agreement was low.

TABLE 1:

TEACHERS' BELIEFS ABOUT THE IMPORTANCE OF FORMATIVE ASSESSMENT

\begin{tabular}{|c|c|c|c|c|c|c|c|c|c|c|c|c|c|}
\hline & \multirow[t]{3}{*}{ Item } & \multirow{2}{*}{\multicolumn{2}{|c|}{$\begin{array}{l}1 \\
\text { Strongly } \\
\text { disagree }\end{array}$}} & \multirow{2}{*}{\multicolumn{2}{|c|}{$\begin{array}{l}2 \\
\text { Disagree }\end{array}$}} & \multirow{2}{*}{\multicolumn{2}{|c|}{$\begin{array}{l}3 \\
\text { Undecided }\end{array}$}} & \multirow{2}{*}{\multicolumn{2}{|c|}{ Agree }} & \multirow{2}{*}{\multicolumn{2}{|c|}{$\begin{array}{l}5 \\
\text { Strongly } \\
\text { agree }\end{array}$}} & \multirow[t]{3}{*}{ Mean } & \multirow[t]{3}{*}{ SD } \\
\hline & & & & & & & & & & & & & \\
\hline & & $\mathrm{F}$ & $\%$ & $F$ & $\%$ & $F$ & $\%$ & $\mathrm{~F}$ & $\%$ & $\mathrm{~F}$ & $\%$ & & \\
\hline 1 & $\begin{array}{l}\text { Assessment results tell me how well I have taught my } \\
\text { students. }\end{array}$ & 0 & 0 & 1 & 4 & 4 & 16 & 10 & 40 & 10 & 40 & 4.22 & 0.82 \\
\hline 2 & $\begin{array}{l}\text { Assessment and evaluation results are important for in- } \\
\text { struction. }\end{array}$ & 0 & 0 & 0 & 0 & 0 & 0 & 9 & 36 & 16 & 64 & 4.64 & 0.49 \\
\hline 3 & My instruction is tied closely to student assessment results. & 0 & 0 & 5 & 20 & 2 & 8 & 11 & 44 & 7 & 28 & 3.8 & 1 \\
\hline 4 & $\begin{array}{l}\text { Assessment and evaluation create competition among } \\
\text { students. }\end{array}$ & 1 & 4 & 1 & 4 & 3 & 12 & 12 & 48 & 8 & 32 & 4.0 & 1 \\
\hline 5 & $\begin{array}{l}\text { Assessments provide a valuable leaming experience for } \\
\text { students. }\end{array}$ & 0 & 0 & 0 & 0 & 1 & 4 & 13 & 52 & 11 & 44 & 4.40 & 0.58 \\
\hline 6 & $\begin{array}{l}\text { Assessment results have an important effect on student self- } \\
\text { concept. }\end{array}$ & 0 & 0 & 1 & 4 & 3 & 12 & 12 & 48 & 9 & 36 & 4.16 & 0.8 \\
\hline 7 & Assessment and evaluation improve students' learning. & 0 & 0 & 1 & 4 & 0 & 0 & 12 & 48 & 12 & 48 & 4.40 & 0.71 \\
\hline 8 & Assessments and evaluations make my students work harder. & 0 & 0 & 0 & 0 & 4 & 16 & 9 & 36 & 12 & 48 & 4.32 & 0.75 \\
\hline 9 & Ineed a variety of assessment methods to assess my students. & 0 & 0 & 2 & 8 & 0 & 0 & 8 & 32 & 15 & 60 & 4.44 & 0.87 \\
\hline
\end{tabular}


As depicted from the above table, $80 \%$ of the respondents agree that assessment results tell them how well they have taught their students $(\mathrm{M}=4.22, \mathrm{SD}=0.82)$ while only $4 \%$ of them disagreed. All of the respondents $(100 \%)$ agreed that assessment and evaluation results are important for instruction $(\mathrm{M}=4.64, \mathrm{SD}=0.49)$. Also, most instructors (72\%) showed their agreement that instruction is tied closely to student assessment results $(\mathrm{M}=3.8, \mathrm{SD}=1)$. Only $20 \%$ of them believe there is no connection between assessment result and instruction. The above responses generally demonstrate instructors' positive belief towards the role of assessment in informing teaching.

On the other hand, $80 \%$ of the instructors reported their agreement with the idea that assessment and evaluation create competition among students $(\mathrm{M}=4.0, \mathrm{SD}=1)$ while $8 \%$ of them disagreed. Almost all instructors $(96 \%)$ reported that assessments provides a valuable learning experience for students $(\mathrm{M}=4.40, \mathrm{SD}=0.48)$ and none of them disagreed. Most of them (84\%) answered assessment results have an important effect on student self-concept $(\mathrm{M}=4.16, \mathrm{SD}=0.8)$ though only few (4\%) disagreed. Again, almost all respondents $(96 \%)$ agreed that assessment and evaluation improve students' learning $(\mathrm{M}=4.40, \mathrm{SD}=0.71)$, but very few of them (4\%) disagreed. On the other hand, most instructors $(84 \%)$ agreed assessments and evaluations make students work harder $(\mathrm{M}=4.32, \mathrm{SD}=0.75)$, and there is no respondent disagreed. Finally, 92\% of the respondents reported that they need a variety of assessment methods to assess their students $(\mathrm{M}=4.44, \mathrm{SD}=0.87)$ and only $8 \%$ of them disagreed.

Generally, all participants rated the items positively and the obtained mean scores were all above 4.0 except only one item and the overall mean was 4.26. All in all $86.5 \%$ agreed formative assessment is important for enhancing instruction and student learning, which reveals that the instructors' belief towards the importance of formative assessment is very good.

TABLE 2:

TEACHERS’ PERCEIVEd Practice OF Formative ASSESSMENT (MONITORING)

\begin{tabular}{|c|c|c|c|c|c|c|c|c|c|c|c|c|c|}
\hline & \multirow[t]{3}{*}{ Item } & \multirow{2}{*}{\multicolumn{2}{|c|}{$\begin{array}{l}1 \\
\text { Strongl } \\
\mathrm{y} \\
\text { disagre } \\
\mathrm{e}\end{array}$}} & \multirow{2}{*}{\multicolumn{2}{|c|}{$\begin{array}{l}2 \\
\text { Disagree }\end{array}$}} & \multirow{2}{*}{\multicolumn{2}{|c|}{$\begin{array}{l}3 \\
\text { Undecide } \\
d\end{array}$}} & \multirow{2}{*}{\multicolumn{2}{|c|}{ Agree }} & \multirow{2}{*}{\multicolumn{2}{|c|}{$\begin{array}{l}5 \\
\text { Strongly } \\
\text { agree }\end{array}$}} & \multirow{3}{*}{ Mean } & \multirow{3}{*}{$\begin{array}{l}\text { Stand } \\
\text { ard } \\
\text { deviat } \\
\text { ion }\end{array}$} \\
\hline & & & & & & & & & & & & & \\
\hline & & F & $\%$ & $F$ & $\%$ & $F$ & $\%$ & $\mathrm{~F}$ & $\%$ & $\mathrm{~F}$ & $\%$ & & \\
\hline 10 & $\begin{array}{l}\text { I encourage my students to reflect upon how they can improve their } \\
\text { writing. }\end{array}$ & 0 & 0 & 2 & 8 & 3 & 12 & 7 & 28 & 13 & 52 & 4.24 & 1.0 \\
\hline 11 & $\begin{array}{l}\text { I involve my students in thinking about how they want to leam } \\
\text { writing. }\end{array}$ & 0 & 0 & 7 & 28 & 5 & 20 & 13 & 52 & 0 & 0 & 3.24 & 0.9 \\
\hline 12 & $\begin{array}{l}\text { I give my students the opportunity to decide on their leaming } \\
\text { objectives. }\end{array}$ & 0 & 0 & 9 & 36 & 4 & 16 & 10 & 40 & 2 & 8 & 3.20 & 1.0 \\
\hline 13 & $\begin{array}{l}\text { I ask my students to indicate what went well and what went badly } \\
\text { concerning their assignments. }\end{array}$ & 1 & 4 & 3 & 12 & 1 & 4 & 18 & 72 & 2 & 8 & 3.68 & 0.9 \\
\hline 14 & $\begin{array}{l}\text { I encourage students to reflect upon their leaming processes and } \\
\text { how to improve their learning. }\end{array}$ & 1 & 4 & 7 & 28 & 2 & 8 & 12 & 48 & 3 & 12 & 3.36 & 1.0 \\
\hline 15 & $\begin{array}{l}\text { I inform my students on their strong points concerning their } \\
\text { learning. }\end{array}$ & 1 & 4 & 2 & 8 & 4 & 16 & 11 & 44 & 7 & 28 & 3.84 & 1.0 \\
\hline 16 & $\begin{array}{l}\text { I inform my students on their weak points concerning their } \\
\text { learning. }\end{array}$ & 0 & 0 & 5 & 20 & 3 & 12 & 12 & 48 & 5 & 20 & 3.68 & 1.0 \\
\hline 17 & I encourage my students to improve on their learning processes. & 0 & 0 & 3 & 12 & 3 & 12 & 7 & 28 & 12 & 48 & 4.12 & 1.0 \\
\hline 18 & I give students guidance and assistance in their learning of writing. & 0 & 0 & 1 & 4 & 0 & 0 & 10 & 40 & 14 & 56 & 4.48 & 0.7 \\
\hline 19 & $\begin{array}{l}\text { I discuss with my students the progress they have made in leaming } \\
\text { writing. }\end{array}$ & 0 & 0 & 1 & 4 & 0 & 0 & 10 & 40 & 14 & 56 & 4.48 & 0.7 \\
\hline 20 & $\begin{array}{l}\text { Together with my students, I consider ways on how to improve on } \\
\text { their weak points. }\end{array}$ & 1 & 4 & 3 & 12 & 2 & 8 & 8 & 32 & 11 & 44 & 4.0 & 1.0 \\
\hline
\end{tabular}

Table 2 shows that $80 \%$ of the teachers encourage their students to reflect up on how they can improve their writing $(\mathrm{M}=4.24, \mathrm{SD}=1.0)$. Only $8 \%$ of them disagreed and $12 \%$ of them were hesitant weather to encourage their students or the other way round. Almost half of the respondents $(52 \%)$ reported that they involve students in thinking about how they want to learn writing $(\mathrm{M}=3.24, \mathrm{SD}=0.9)$ and $28 \%$ of them replied they don't involve their students where as the other $20 \%$ couldn't decide whether or not they encourage students. It was also reported that less than half of the participant teachers $(48 \%)$ give their students the opportunity to decide on their learning objectives $(\mathrm{M}=3.2, \mathrm{SD}=1.0)$, but $36 \%$ reported they don't give this opportunity. On the other hand, $80 \%$ respondents expressed that they ask their students to indicate what went well and what went badly regarding assignments $(\mathrm{M}=3.68, \mathrm{SD}=0.9)$ while $16 \%$ of them reported that they do not do this. $60 \%$ encourage students to reflect upon their learning processes and how to improve learning $(\mathrm{M}=3.36, \mathrm{SD}=1.0)$ where as $32 \%$ of the respondents do not give this chance for their students. The majority (72\%) inform students on their strong points concerning their learning $(\mathrm{M}=3.84, \mathrm{SD}=1.0)$ and only $12 \%$ of the teachers do not indicate the strong points. Similarly, $68 \%$ of the teachers show students the weak points in their learning $(\mathrm{M}=3.68, \mathrm{SD}=1.0)$ whereas only few of them $(5 \%)$ disagreed on the idea of this. $76 \%$ teachers encourage students to improve their learning processes $(\mathrm{M}=4.12, \mathrm{SD}=1.0)$ and $12 \%$ of them do not. Almost all $(96 \%)$ teachers reported to give students guidance and assistance in their learning of writing $(\mathrm{M}=4.48, \mathrm{SD}=0.7)$, but only $4 \%$ replied that they do not. Likewise, 96\% participants agreed that they discuss with students the progress they have made in learning writing $(\mathrm{M}=4.48, \mathrm{SD}=0.7)$ and only $4 \%$ denied doing so. Most respondents $(76 \%)$ replied that they consider ways on how to improve on their weak points together with students $(\mathrm{M}=4.0, \mathrm{SD}=1.0)$ and only $16 \%$ replied they do not. 
To sum up, participants generally rated the items positively but more than half of the means were below 4.0 and the overall mean was 3.84. What is more, all in all $74 \%$ agreed they monitor learners through assessment. It is possible to deduce here that teachers' practice of formative assessment through monitoring was rather medium.

TABLE 3:

TEACHERS’ PERCEIVED PRACTICE OF Formative ASSESSMENT (SCAFFOLDING)

\begin{tabular}{|c|c|c|c|c|c|c|c|c|c|c|c|c|c|}
\hline & \multirow[t]{3}{*}{ Item } & \multirow{2}{*}{\multicolumn{2}{|c|}{$\begin{array}{l}1 \\
\text { Strongly } \\
\text { disagree }\end{array}$}} & \multirow{2}{*}{\multicolumn{2}{|c|}{$\begin{array}{l}2 \\
\text { Disagree }\end{array}$}} & \multirow{2}{*}{\multicolumn{2}{|c|}{$\begin{array}{l}3 \\
\text { Undecid } \\
\text { ed }\end{array}$}} & \multirow{2}{*}{\multicolumn{2}{|c|}{$\begin{array}{ll}4 \\
\text { Agree }\end{array}$}} & \multirow{2}{*}{\multicolumn{2}{|c|}{$\begin{array}{l}5 \\
\text { Strongly } \\
\text { agree }\end{array}$}} & \multirow[t]{3}{*}{ Mean } & \multirow[t]{3}{*}{$\mathrm{SD}$} \\
\hline & & & & & & & & & & & & & \\
\hline & & $\mathrm{F}$ & $\%$ & F & $\%$ & F & $\%$ & F & $\%$ & $\mathrm{~F}$ & $\%$ & & \\
\hline 21 & $\begin{array}{l}\text { I adjust my teaching whenever I notice that my students do not } \\
\text { understand a topic. }\end{array}$ & 3 & 12 & 13 & 52 & 5 & 20 & 4 & 16 & 0 & 0 & 2.40 & 0.9 \\
\hline 22 & $\begin{array}{l}\text { I provide my students with guidance to help them gain understanding } \\
\text { of the content taught. }\end{array}$ & 1 & 4 & 0 & 0 & 1 & 4 & 12 & 48 & 11 & 44 & 4.28 & 0.9 \\
\hline 23 & $\begin{array}{l}\text { During my class, students are given the opportunity to show what } \\
\text { they have learned. }\end{array}$ & 0 & 0 & 2 & 8 & 1 & 4 & 10 & 40 & 12 & 48 & 4.28 & 0.9 \\
\hline 24 & $\begin{array}{l}\text { By asking questions during class, I help my students gain } \\
\text { understanding of the content taught. }\end{array}$ & 0 & 0 & 0 & 0 & 0 & 0 & 15 & 60 & 10 & 40 & 4.40 & 0.5 \\
\hline 25 & I am open to student contribution in my class. & 2 & 8 & 5 & 20 & 5 & 20 & 11 & 44 & 2 & 8 & 3.24 & 1.0 \\
\hline 26 & $\begin{array}{l}\text { I ensure that my students know what areas they need to work on in } \\
\text { order to improve their results. }\end{array}$ & 0 & 0 & 4 & 16 & 3 & 12 & 11 & 44 & 7 & 28 & 3.84 & 1.0 \\
\hline 27 & I give my students opportunities to ask questions. & 1 & 4 & 2 & 8 & 0 & 0 & 16 & 64 & 6 & 24 & 3.96 & 1.0 \\
\hline 28 & My students know what the evaluation criteria for their work are. & 0 & 0 & 6 & 24 & 4 & 16 & 9 & 36 & 6 & 24 & 3.60 & 1 \\
\hline 29 & $\begin{array}{l}\text { I ensure that my students know what they can leam from their } \\
\text { assignments. }\end{array}$ & 1 & 4 & 1 & 4 & 4 & 16 & 14 & 56 & 5 & 20 & 3.84 & 0.9 \\
\hline 30 & I can recognize when my students reach their learning goals. & 1 & 4 & 5 & 20 & 5 & 20 & 14 & 56 & 0 & 0 & 3.28 & 0.9 \\
\hline
\end{tabular}

The above table shows only $16 \%$ of the teachers adjust their teaching whenever they notice that students do not understand a topic $(\mathrm{M}=2.8, \mathrm{SD}=0.9)$ and the majority of them $(64 \%)$ disagreed with the idea of adjusting lessons based on how much their students understood from the teaching. Some of them $(20 \%)$ hesitated whether to agree or disagree. Most of them (92\%) agreed they provide students with guidance to help them gain understanding of the content taught $(\mathrm{M}=4.2, \mathrm{SD}=0.9)$ and only one respondent $(4 \%)$ reported that no guidance is given. Similarly, the majority of them (88\%) reported students are given the opportunity to show what they have learned during class time $(\mathrm{M}=4.28, \mathrm{SD}=0.9)$ while only $8 \%$ of them disagreed with the provision of this opportunity. All of the respondents (100\%) agreed that they help students gain understanding of the content taught by asking questions during class $(\mathrm{M}=4.40, \mathrm{SD}=0.5)$.

About half of the participants (52\%) reported they are open to student contribution ( $\mathrm{M}=3.24, \mathrm{SD}=1.0)$ whereas $28 \%$ of them did not agree. However, the rest (20\%) made no decision if they are open or the other way round. Again, the majority of them (72\%) agreed they ensure that their students know what areas they need to work on in order to improve results $(\mathrm{M}=3.84, \mathrm{SD}=1.0)$, but only few $(16 \%)$ of them disagreed. On the other hand, $88 \%$ teachers give students opportunities to ask questions $(\mathrm{M}=3.96, \mathrm{SD}=1.0)$ while only $12 \%$ of them disagreed with giving this chance to their students. $60 \%$ of the participants agreed students know what the evaluation criteria for their work are $(\mathrm{M}=3.60$, $\mathrm{SD}=1.0$ ) though $24 \%$ of them disagreed with the idea. $76 \%$ reported they ensure that students know what they can learn from their assignments $(\mathrm{M}=3.84, \mathrm{SD}=0.9)$ while $8 \%$ denied ensuring what students can learn from assignments. Finally, $56 \%$ reported as if they can recognize when their students reach their learning goals $(\mathrm{M}=3.28, \mathrm{SD}=0.9)$ whereas $24 \%$ of them disagreed.

In summary, participants rated all the items positively, but more than half of the means were below 4.0, and overall mean was 3.71. All in all, $70 \%$ of the teachers agreed on their practice of formative assessment through scaffolding. This implies that teachers' practice of scaffolding students is medium.

TABLE 4:

The RELATIONSHIP BETWEEN TEACHERS' BELIEFS AND PRACTICES OF FORMATIVE AsSESSMENT

\begin{tabular}{llll}
\hline Variables & & Belief & Practice \\
\hline Belief & Pearson Correlation & 1 & $.569^{* *}$ \\
& Sig. (2-tailed) & & .003 \\
& N & 25 & 25 \\
Practice & Pearson Correlation & $.569^{* *}$ & 1 \\
& Sig. (2-tailed) & .003 & 25 \\
\hline & N & 25 & \\
\hline & $* *$. Correlation is significant at the 0.01 level (2-tailed).
\end{tabular}

As displayed in the above table (Table 4), a Pearson correlation was calculated in order to examine the relationship between teachers' beliefs and their actual practices. A moderate, positive, and significant correlation was found between the two variables $\mathrm{r}(23)=.569, \mathrm{p}<0.01)$, with a high level of instructors' belief in the importance of formative assessment to enhance student learning associated with high level of their actual practice of formative assessment.

\section{B. Analysis of the Qualitative Data}

In this section, the data gathered through open-ended questionnaire items, semi-structured interview, and students' paragraphs and essays were analyzed and interpreted using description and thematic categorization techniques.

\section{Data from Open-ended Questionnaire Items}


With the thirty close-ended questionnaire items, three general open-ended questions were used to elicit more information. Instructors expressed their belief that assessment assists to enhance students' learning and to improve the quality of instruction. They added that formative assessment is essential for students and teachers to locate their position in the process of teaching and learning and take remedial actions. Therefore, it can be said that teachers have a positive belief toward the importance of formative assessment.

Regarding their practice of formative assessment, however, instructors confessed that they do not have good practice of it due to a range of challenges. One of the challenges repeatedly mentioned was time constraint. They mentioned that the allotted time for the course is not adequate to assess students with a variety of tasks and to use the feedback from the assessment to shape teaching. The large class size which stretches up to sixty in a class and the students' illegible handwritings were also found to be other common setbacks which obstruct teachers from giving a variety of tasks and timely feedback for students. As instructors explained, they usually give continuous objective tests which aim at judging the extent of students' achievement on the contents covered in the course, and the feedback from these test results is not used to identify learning gaps and fill them, but rather to collect marks for reporting grades.

\section{Data from Semi-structured Interview}

In addition to the data gathered through open-ended questionnaire items, three randomly selected instructors among the participants were subjected to semi-structured interview. Like the responses to the open-ended questions, teachers felt no doubt that formative assessment has a central role in the teaching/learning process. They justified that this kind of assessment helps students and teachers to identify gaps and take appropriate measures of remediation.

The interviewees think that they are practicing formative assessment to a great extent only because they give subsequent tests which include individual paper and pencil tests, performance tests, group assignment and final exam all of which for summative purposes only. As they articulated, sometimes students even take test after test without receiving feedback on the first one. Therefore, although the quantitative data showed that instructors have a positive belief about the importance of formative assessment and they moderately practice it, the qualitative data does not support this.

3. Data from Students' Assessment Papers

To consolidate the qualitative data from open-ended questionnaire items and semi-structured interview, examining real experience of instructors' formative assessment practice by looking in to samples of students' paragraphs and essays with teachers' feedback was vitally important. The analysis focused on which features (components) of the composition writing instructors paid attention to, and the manner the feedback is given.

Accordingly, the instructors' actual practice showed that they mostly give indirect feedback by just underlining, or circling the part of students' writing with a problem. Almost all the students' writing problems observed by instructors are mechanical (spelling, capitalization and punctuation) and some of them are grammatical (e.g. agreement $\&$ number). Feedback regarding the most important aspects in composition writing, such as content, organization and language use is nonexistent. In some cases, teachers give a direct feedback by crossing over the wrong expression and substituting the correct version above it. This sort of teachers' feedback practice ignores the basic components that formative feedback constitutes: what was done well, what needs improvement, and how to improve it. Therefore, these instructors' formative assessment practice is poor. Firstly, as teachers are not focused on aspects planned prior to the assessment, they are mostly attracted by easily observable mechanical errors. As a result, students' errors of basic composition writing components, such as content, organization and language use are left unrecognized. Second, the way they give feedback does not seem appropriate because only circling, underlining, or crossing over errors and writing the correct version above them has very little to do with tackling similar problems for the future. As a result, the feedback does not serve to adjust feature learning and teaching.

\section{RESULTS AND DiSCUSSION}

This study aimed to assess EFL teachers' beliefs and practice of formative assessment in teaching writing skills. To this effect, it employed a mixed research approach with explanatory design. Data were gathered from participants through questionnaire, semi-structured interview and students' marked paragraph and essay papers. Analyzing the data from the three sources through descriptive statistics, inferential statistics (correlation) and thematic categorization, it was found that Debre Markos University writing skills teachers have a positive belief about the importance of formative assessment in enhancing student learning and instruction. It was found that $86.5 \%$ of the respondents agreed on the importance of formative assessment for enhancing instruction and student learning.

The teachers' practice of formative assessment through monitoring the students' learning is at medium level. Only $74 \%$ of the subjects agreed that they monitor learners through assessment which, according to the set criteria of formative assessment practice, is medium level. In addition, the teachers' practice of formative assessment through scaffolding the students with weaknesses was found to be at medium level, too. Only $70 \%$ of the teachers agreed on their practice of formative assessment through scaffolding. This magnitude of formative assessment practice, according to the criteria, is labeled as medium. Statistically, the relationship between teachers' beliefs and their actual practice was found to be positive, moderate and significant ( $\mathrm{r}(23)=.569, \mathrm{p}>0.01)$. However, the finding from qualitative data analysis contradicts this. There is a mismatch between teachers' beliefs and their perceived practice. 
As the findings revealed EFL instructors have a positive belief on the importance of formative assessment to improve student learning, but their practice in terms of monitoring their students' learning and scaffolding when shortcoming arise was not found as such good. Writing instructors give continuous tests, rather than continuously assessing their students formatively in order to get insights about the teaching and learning. In the way these instructors are practicing assessment, there is no room for both instructors and students to remediate based on the feedback. This finding is consistent with Mebea's (2008) and Dagne's (2009) result that the practice of continuous assessment at their respective college was not promising. Likewise, Habtamu's (2012) and Abiy' (2013) findings of low practice of continuous assessment in Jimma University and high school EFL teachers, respectively match with the finding of the current study. In like manner, Öz's (2014) finding revealed that most teachers rely on conventional methods of summative assessment rather than formative assessment processes. This international reality of formative assessment practice is similar with the finding in the context of Ethiopia.

\section{CONCLUSION}

Based on the findings of the study, it was concluded that writing skills instructors of Debre Markos University have a positive belief on the importance formative assessment. In other words, they believe that formative assessment is important for maximizing instruction and student learning. In addition, their perceived practice of formative assessment through monitoring students' learning and scaffolding learners with certain shortcomings was found to be at medium level, which revealed that there are limitations on instructors' practice in this respect.

The relationship between the instructors' beliefs and their actual practices of formative assessment, as determined from the Pearson product-moment correlation coefficient, was found to be moderate, positive and significant ( $\mathrm{r}$ (23) $=.569, \mathrm{p}<0.01$ ). However, the data from open-ended questions, interview and document showed that the formative assessment practice in the writing class is not promising. It was also pointed out that there are setbacks which hinder the practice, which include time constraint to finish the contents of the course, the large and unmanageable class size to give subsequent and appropriate assessment (feedback), and the students' illegible hand-writing being tiresome to correctly mark and give feedback.

\section{REFERENCES}

[1] Abiy, Y. (2013). High school English teachers' and Students' perceptions, attitudes and actual practices of continuous assessment. Academic Journals. 8(16), 1489-1498.

[2] Alamirew, G. (2005). The Perception of Writing, Writing Instruction, and Students' Writing Performance. PhD Dissertation. AAU.

[3] Bekele, B (2011). Promoting Self-regulated Learning in Writing Classes: Effects on Self-beliefs and Performances. PhD Dissertation. AAU.

[4] Black, P. \& Wiliam, D. (1998). Assessment and Classroom Learning. Assessment in Education, 5(1), 7-71.

[5] Black, P. and D. Wiliam. (2003). "In Praise of Educational Research. Formative Assessment", British Educational Journal, 29(5), 623-637.

[6] Black, P. J., \& Wiliam, D. (2009). Developing the theory of formative assessment, Educational Assessment, Evaluation and Accountability, 21(1), 5-31.

[7] Brookhart, S.M. (2008). How to Give Effective Feedback to Your Students.USA: Association for Supervision and Curriculum Development.

[8] Campbell, A. and Norton, L. (eds.) (2007). Learning, Teaching and Assessing in Higher Education: Developing Reflective Practice. UK: Learning Matters Ltd.

[9] Cumming, A. (2009). The Contribution of Studies of Foreign Language Studies to Research, Theories, and Policies. In Manchoin, R.M. (2009 ed). Writing in Foreign Language Contexts: Learning, Teaching, and Research. UK: Multilingual Matters.

[10] Dagne, T. (2009). The Exploration of the Practices of Continuous Assessment by EFL Instructors: the Case of Jimma Teachers College (Unpublished MA thesis).

[11] Elashri, A.F. and Elshirbini, I. I. (2013). The Impact of the Direct Teacher Feedback Strategy on the EFL Secondary Stage Students' Writing Performance, Unpublished PhD Thesis, Mansoura University.

[12] Geremew, L. (1999). A Study of the Requirements in Writing for Academic Purposes At Addis Ababa University: Four Departments in Focus. PhD Thesis. AAU.

[13] Habtamu, T. (2009). EFL Instructors' Implementation of Continuous Assessment with Reference to $2^{\text {nd }}$ and 3 rd year English Department Students of Dilla University. AAU: Unpublished MA Thesis.

[14] Haregewain, A. (2008). The Effect of Communicative Grammar on the Grammatical Accuracy of Students' Academic Writing: An Integrated Approach to TEFL. PhD Thesis. AAU.

[15] Heritage, M. (2008). Learning Progressions: Supporting Instruction and Formative Assessment. USA: CCSSO.

[16] Heritage, M. (2010). Formative Assessment: Making It Happen in the Classroom. USA: Corwin

[17] Lee, I. (2011). Formative Assessment in EFL Writing: An Exploratory Case Study. Hong Kong: Routledge. Changing English. 18(1), 99-111.

[18] Lumpur, K. (2013). Iranian Secondary School EFL Teachers' Assessment Beliefs and Roles. Life Science Journal. 10(3), 16381647.

[19] Meba, F. (2008). The Challenges of Implementing Continuous Oral assessment in EFL Classes with Reference to Dbre-Berhan Teachers' College (Unpublished MA Thesis). 
[20] Nicol, D.J and Macfarlane-Dick, D. (2006). Formative Assessment and Self-regulated Learning: A Model and Seven Principles of Good Feedback Practice. Studies in Higher Education, 31(2), 199-218

[21] Öz, H. (2014). Turkish Teachersee Practices of Assessment for Learning in the English as a Foreign Language Classroom. Journal of Language Teaching and Research, 5(4), 775-785.

[22] Sadler, D.R (1989). Formative Assessment and the Design of Instructional Systems. Australia: Netherlands.

[23] Sadler, D.R. (1998). Formative Assessment: Revisiting the Territory. Assessment in Education, 5(1), 77-84.

[24] The Cross Sectoral Assessment Working Party (June, 2011). Teachers' Guide to Assessment. Retrieved from https://www.education.act.gov.au/teaching_and.../teachers_guide_to_assessment.

[25] Weigle. C. S. (2002). Assessing Writing. Cambridge: Cambridge University Press.

[26] Zewdu, E. (2012). An Investigation into the Research Culture of Addis Ababa University: The Case of Teaching English as a Foreign Language (TEFL) PhD Program. PhD Thesis. AAU.

[27] Zheng, H. (2015). Teacher Beliefs as a Complex System: English Language Teachers in China. Switzerland: Springer International Publishing.

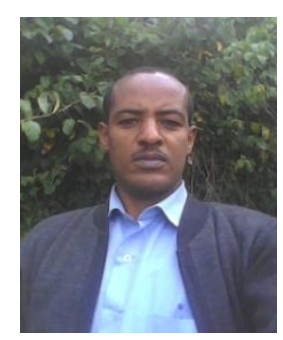

Zelalem Berhanu Guadu is a lecturer of Teaching English as a Foreign Language in the College of Social Sciences and Humanities in the Department of English Language and Literature at Debre Markos University, Ethiopia. He is currently a doctoral student in the Department of English Language and Literature at Bahir Dar University, Ethiopia. His research interest is formative assessment in the teaching of writing. Email: zelalemberhanu29@yahoo.com

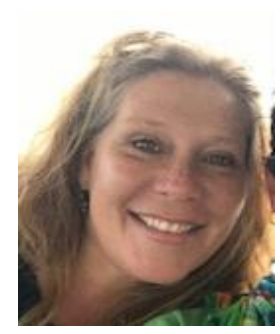

Emily Joy Boersma is an Assistant Professor in TEFL at Bahir Dar University in Ethiopia.

She has taught EFL/ESL on all continents, apart from Antarctica, over the past 20 years. She enjoys teaching courses such as Second Language Acquisition and Issues in Language Teaching to doctoral students; Academic Writing for Master's students and Spoken for freshman Bachelors students. She also enjoys coordinating the English Language Improvement Center at BDU. Her research interests include ESL, technology in the language classroom, and language games. Email: emily_boersma@yahoo.com 